\title{
PENGEMBANGAN DAN PENINGKATAN KINERJA BANK \\ PEMBIAYAAN RAKYAT SYARIAH (BPRS) DAARUT TAUHID DALAM RANGKA MENINGKATKAN KESEJAHTERAAN UMAT
}

\author{
Rahmat \\ rahmat@ekuitas.ac.id \\ Dadang Agus Suryanto \\ a.32Surya@gmail.com \\ Endang Ruchiyat \\ endru_mr@yahoo.com
}

SEKOLAH TINGGI ILMU EKONOMI EKUITAS

\begin{abstract}
ABSTRAK
Program pengabdian masyarakat ini bertujuan memberikan pembinaan tentang pengembangan kinerja BPRS dan memberikan pemahaman tentang penerapan tata kelola BPRS yang baik, berdasarkan pertimbangan pemikiran bahwa BPRS sangat berperan dalam memberdayakan ekonomi umat berdasarkan prinsip Syariah dengan mengembangkan golongan ekonomi lemah yaitu Usaha Mikro, Kecil, dan Menengah (UMKM). Kegiata pengabdian melibatkan pengurus, pejabat eksekutif dan pegawai BPRS. Melalui program pengabdian tersebut memberikan nilai tambah dan manfaat khusunya untuk BPRS Daarut Tauhid, sehingga dapat mengelola Dana dengan baik dan menyalurkan pembiayaan kepada UMKM meningkat. Berkembangnya usaha dan berjalannya prinsip-prinsip tata kelola yang baik diantaranya terdapat kelengkapan kebijakan, pedoman/SOP, peningkatan kualitas Sumber Daya Insani, penataan teknologi akuntasi, serta adanya perluasan jaringan, kinerja BPRS Daarut Tauhid semakin tumbuh dan berkembang, UMKM berkembang berdampak pula pada meningkatnya kesejahteraan umat. Keberadaan BPRS Daarut Tauhid juga memberikan pengaruh terhadap terjadinya pengembangan ekonomi Syariah pada daerah tersebut.
\end{abstract}

Kata kunci: BPRS, Daarut Tauhid, UMKM, Kesejahteraan, Umat.

\section{PENDAHULUAN}

Persaingan pada industri perbankan semakin tajam, baik antar bank umum maupun bank syariah, Bank Perkreditan Rakyat (BPR)/Bank Pembiayaan Rakyat Syariah (BPRS), dan juga munculnya Fintech dengan perangkat teknologi yang memadai. Hal tersebut perlu menjadi perhatian BPRS yang melayani nasabah di daerah agar mampu bersaing dan mampu bertahan serta berkembang secara berkesinambungan.

BPRS menurut Undang-undang nomor 21 tahun 2008 tentang Perbankan Syariah adalah Bank Syariah yang dalam kegiatannya tidak memberikan jasa dalam lalu lintas pembayaran. Bp BPRS mempunyai potensi untuk tumbuh dan berkembang, karena menggunakan pola bagi hasil yang menjadi daya tarik 
masyarakat di daerah. Dalam upaya membuka peluang kegiatan usahanya perlu ditunjang dengan strategi, menurut Johnson and Scholes, strategi adalah arah dan ruang lingkup sebuah organisasi dalam jangka panjang yang mencapai keuntungan bagi organisasi melalui konfigurasi sumber daya dalam lingkungan yang menantang, untuk memenuhi kebutuhan pasar dan memenuhi harapan pemangku kepentingan. Strategi dapat diterapkan pada tata kelola, inovasi produk, dan pemasaran.

Strategi tersebut akan menciptakan kinerja BPRS yang saling menguntungkan baik untuk BPRS maupun untuk nasabah, khususnya yang bergerak di bidang UMKM karena akan tercipta pelayanan prima BPRS terhadap nasabahnya, juga untuk BPRS akan memperoleh pendapatan yang memadai. Dengan tata kelola yang baik dapat meminimalisir risiko. Strategi Tata kelola yaitu dengan menerapkan prinsip Good Corpote Governance (GCG) adalah Tata kelola perusahaan yang baik yaitu suatu sistem yang mengatur hubungan peran Dewan Komisaris, peran Direksi, pemegang saham, dan pemangku kepentingan lainnya. Tata kelola perusahaan yang baik juga disebut sebagai suatu proses yang transparan atas penentuan tujuan perusahaan, pencapaiannya, dan penilaian kinerjanya (Agoes Sukrisno (2011:101): Prinsip GCG menurut National Committe on Governance (2006), terdapat 5 (lima) Prinsip, yaitu Transparansi, Akuntabilitas, Responsibilitas, Indenpendensi, dan Kesetaraan. Penerapan GCG harus di dukung dengan kebijakan serta pedoman kerja/SOP diantaranya pedoman GCG, Kepatuhan, Manajemen Risiko, Standar layanan. Strategi inovasi produk dilakukan degan menciptakan produk yang menarik dan mampu bersaing dengan produk bank lain. Strategi Pemasaran diantaranya menciptakan layanan dengan menggunakan teknologi untuk memudahkan dan mempercepat interaksi antara BPRS dengan masyarakat. Disamping itu dalam meningkatkan penghimpunan dana masyarakat perlu dilakukan sosialisasi dan promosi kepada masyarakat tentang keberadaan dan keunggulan BPRS. Dalam menjalankan strategi pengembangan BPRS perlu ditunjang dengan kuantitas Sumber Daya Insani yang memadai ditunjang dengan kualitasnya yang dapat ditingkatkan melalui pendidikan dan pelatihan, baik intern maupun bekerjasama dengan lembaga pendidikan yang relevan dengan bisnis BPRS.

BPRS Daarut Tauhiid adalah revolusi dari pada BPRS Ishlahul Ummah, dengan perubahan nama yang terjadi, diharapkan menjadi bank yang dapat memberikan hal hal positif serta memberikan sumbangsih dakwah ekonomi berdasarkan syariah pada umat.

Ishlahul Ummah merupakan BPR Syariah yang beroperasi sejak tahun 1994, bertujuan membangun ekonomi umat demi kemaslahatan bersama, oleh karena itu Ishlahul Ummah senantiasa berupaya melayani semua kebutuhan umat.

PT. BPR Syariah Ishlahul Ummah didirikan dengan akta tertanggal 27 Januari 1994 nomor 161 yang telah dibuat di hadapan Notaris Irdam Noezar, SH. sebagai pengganti Notaris Wiratni Ahmadi, SH di Bandung, dan telah mendapat pengesahan Menteri Kehakiman Republik Indonesia berdasarkan Surat Keputusannya tertanggal 03 Juni 1994 No. C2-8717 HT.01.01 Tahun 1994. Anggaran dasar PT. BPRS Ishlahul Ummah telah mengalami beberapa kali perubahan dan perubahan terakhir dibuat dihadapan Notaris Detty Triesnawaty, SH, Notaris di Kabupaten Bandung Barat, tertanggal 12 November 2014. Perubahan 
ini telah mendapat persetujuan dari Menteri Hukum dan Hak Asasi Manusia Republik Indonesia tertanggal 09 Desember 2014, nomor AHU-12458.40.20.2014.

Sejak pertengahan tahun 2004, PT. BPRS Ishlahul Ummah berlokasi di Jl. Raya Cilember (Jl. Jendral. H. Amir Mahmud) No. 281 Kelurahan Cigugur Tengah Kecamatan Cimahi Tengah Kota Cimahi, kode pos 40522. Nomor telpon (022) 6613381 No. Fax (022) 6613827. Saat ini BPRS Ishlahul Ummah menjadi BPRS Daarut Tauhiid dengan alamat baru Jl. Amir machmud no 510 Cibabat Cimahi jawa barat Dipilihnya lokasi Pengabdian Masyarakat di BPRS Daarut Tauhid Cimahi, berdasarkan pertimbangan pendiriannya relatip baru dan mempunyai potensi dapat tumbuh dan berkembang, sehingga diharapkan BPRS Daarut Tahid dapat menjangkau masyarakat terutama golongan usaha mikro, kecil dan menengah secara sehat dan Profesional.

Permasalahan yang dihadapi adalah belum optimalnya penghimpunan dana pihak ketiga dan ekspansi pembiayaan kepada para pengusaha UMKM, selain karena persaingan yang tidak bisa terhindarkan yang mempengaruhi pertumbuhan BPRS Daarut Tauhid, juga ditinjau dari prinsip tata kelola masih belum optimal diantaranya terdapat beberapa peraturan/ketentuan/pedoman kerja yang harus dilengkapi dan disempurnakan, perlunya peningkatan kualitas sumber Daya Insani, serta belum diterapkannya manajemen risiko.

Hal tersebut dapat mempengaruhi kinerja. Sebuah bank harus mampu meningkatkan kinerja keuangannya untuk bisa bertahan dan mengembangkan eksistensinya. Kinerja merupakan hal penting yang harus dicapai oleh setiap perusahaan, kinerja sangat penting karena bisnis perbankan adalah bisnis kepercayaan, maka bank harus mampu menunjukkan kredibilitasnya sehingga akan semakin banyak masyarakat yang menggunakan jasa perbankan dalam bertransaksi melaui penerapan prinsip tata kelola yang baik.

\section{Tujuan Pengabdian}

Tujuan pengabdian masyarakat yang diprogramkan pada BPRS Daarut Tauhid adalah ssbb:

1. Melakukan evaluasi kegiatan usaha yang telah dilakukan BPRS Daarut Tauhid dalam rangka meningkatkan kesejahteraan ekonomi umat.

2. Melakukan evaluasi kegiatan usaha BPRS Daarut Tauhid berkaitan dengan kebijakan, dan Pedoman/ SOP.

3. Memberikan sumbangsih pemikian, masukan berupa konsep strategi usaha BPRS dan prinsip tata kelola BPRS, baik dalam penghimpunan dana maupun penyaluran dana dalam upaya meningkatkan kinerja BPRS Daarut Tauhid dan dalam rangka meningkatkan kesejahteraan umat sejalan dengan semangat Ukhuwah islamiyah.

\section{METODOLOGI PELAKSANAAN}

Metode yang digunakan dalam kegiatan sosialisasi pengabdian masyarakat berkaitan dengan peningkatan kinerja dan penerapan prinsip tata kelola BPRS Daarut Tauhid adalah:

1. Metode sosialisasi atau ceramah, presentasi-interaktif, dimana dilakukan sosialisasi utamanya mengenai Undang-undang Bank Syariah, ketentuan kegiatan usaha bank, Kepatuhan bank, Manajemen risiko bank, prinsip-prinsip Good Corporate Governance, dan pelaporan-pelaporan. 
2. Ceramah dilakukan melalui presentasi yang dilakukan secara interaktif, aktif reflektif.

3. Setelah pemaparan materi sosialisasi dilanjutkan dengan diskusi dan tanya jawab mendalam yang dilakukan secara interaktif.

4. Selain ceramah dan diskusi kepada peserta yang hadir juga disebarkan materi penyuluhan, dan penyerahan angket sebagai self assesmen untuk mengetahui kelemahan demi perbaikan lebih lanjut.

5. Memberikan konsultasi kegiatan operasional BPR baik melalui pendampingan maupun melalui media sosial.

Tehnis Pelaksanaan Kegiatan

Pelaksanaan kegiatan dilakukan melalui beberapa tahapan sebagai berikut:

1. Rapat dengan seluruh Tim / panitia tentang pelaksanaan pengabdian masyarakat;

2. Permohonan pelaksanaan pengabdian kepada PT. BPRS Daarut Tauhid;

3. Mempersiapkan seluruh bahan-bahan penyuluhan seperti misalnya membuat power point slide, penggandaan materi, penyiapan Peraturan Perundang-undangan;

4. Pelaksanaan kegiatan pengabdian pada nulan Oktober 2018 sampai bulan Desember 2018 bertempat di Kantor PT BPRS Daarut Tauhid.Jl. Amir machmud no 510 Cibabat cimahi jawa barat dan di pondok pesantren Daarut Tauhid Jl Gegerkalong Girang No. 67 Bandung;

5. Selanjutnya dilakukan tahapan penyelesaian pelaporan hasil kegiatan pengabdian kepada masyarakat pada bulan Januari 2019.

\section{HASIL DAN LUARAN}

1. Kegiatan Usaha Bank Perkreditan Rakyat Syariah (BPRS) Daarut Tauhid

Sasaran sosialisasi kegiatan pengabdian ini adalah pengurus dan pegawai BPRS
Daarut Tauhid. Dengan dilakukannya kegiatan sosialisasi di Kantor Daarut Tauhid dimana terjalin komunikasi dan kerjasama yang baik antara Tim pengabdian masyarakay STIE Ekuitas dengan pihak pengurus dan pegawai PT. BPRS Daarut Tauhid, maka dapat dikemukakan bahwa sasaran kegiatan pengabdian masyarakat ini tercapai dengan baik yang mana terungkap bahwa kegiatan usaha BPRS Daarut Tauhid telah sesuai dengan prinsip prinsip syariah sebaimana diatur dalam Peraturan Otoritas Jasa Keuangan nomor 3 /POJK.03/2016 tentang bank pembiayaan rakyat syariah bahwa dalam melaksanakan kegiatan usaha BPRS wajib menerapkan Prinsip Syariah. Kegiatan usaha tersebut meliputi sbb:

\section{Tabungan}

Tabungan Ishmah merupakan Tabungan

\section{Mudharabah}

Tabungan Maslahat merupakan Tabungan Wadiah yad Dhamanah

\section{Deposito}

Merupakan simpanan berjangka 1 bulan, 3 bulan, 6 bulan, atau 12 bulan dengan akad mudhabarah mutlaqah atau mudharabah muqayyadah

\section{Pembiayaan}

- Piutang Murabahah (MBA)/jual beli

- Pembiaayan Musyarakah (MSA)/ penyertaan

- Pembiayaan Mudharabah (MDA)/ modal kerja

- Ijarah/sewa

- Ijarah Multijasa

- Qordh :- Rahn

- Hawalah

- Qordhul Hasan

Produk syariah PT.BPR Daarut Tauhid telah berjalan melayani umat secara normal, namun belum optimal menjangkau pangsa pasar diwilayah Cimahi dan sekitarnya. Sehingga perlu diupayakan melalui berbagai upaya strategi pemasaran diantaranya melalui sosialisasi keberadaan BPRS Daarut Tauhid dan penciptaan inovasi produk yang menarik minat umat terutama para pengusaha UMKM. Melihat potensi UMKM di wilayah Cimahi dan sekitarnya 
sangat tinggi. Pembiayaan kepada UMKM selain meningkatkan kinerja BPRS Daarut Tauhid juga menciptakan lapangan kerja di bidang UMKM dan meningkatkan pendapatan per kapita serta meningkatkan kesejahteraan umat.

2. Kebijakan dan Pedoman Kegiatan usaha Berdasarkan materi yang telah disampaikan sesuai peraturan perundangundangan yang berlaku dan selanjutnya keseluruhan materi telah dirangkum dalam aplikasi ceklis/self assessment sebagai alat control terhadap hal hal yang telah dilaksanakan, masih dalam proses dan belum dilaksanakan dapat dijadikan acuan untuk melengkapinya, sehingga menjadikan PT. BPRS Daarut Tauhid menjada BPRS yang Profesional. Dari hasil self assessment dapat dikemukakan hal hal sbb:

1) Terdapat Kebijakan dan pedoman yang sudah selesai terutama menyangkut produk produk syariah yaitu Tabungan dan Deposito, sebagaimana diatur dengan Peraturan Otoritas Jasa Keuangan nomor 31/POJK.05/2014 tentang penyelenggaraan usaha pembiayaan syariah.

2) Terdapat Kebijakan dan pedoman yang masih dalam proses penyempurnaan disesuaikan dengan peraturan Otoritas Jasa Keuangan yang up to date diantaranya pedoman APU PPT, sebagaimana diatur dalam POJK nomor 12/POJK.01/2017 tentang penerapan program anti pencucian uang dan pencegahan pendanaan terorisme di sektor jasa keuangan.

3) Terdapat kebijakan dan pedoman yang sama sekali belum ada diantaranya yaitu Pedoman Tata kelola BPRS, sebagaimana diatur dalam Peraturan Otoritas Jasa keuangan Republik indonesia nomor 24 /POJK.03/2018 tentang Penerapan Tata Kelola bagi Bank Pembiayaan Rakyat Syariah, Pedoman fungsi Kepatuhan, sebagaimana diatur dalam Surat Edaran Otoritas Jasa Keuangan nomor 11
/SEOJK.03/2019 tentang Penerapan Fungsi kepatuhan bagi Bank Pembiayaan Rakyat Syariah, Pedoman penerapan manajemen risiko, sebagaimana diatur dalam Peraturan Otoritas Jasa Keuangan Republik Indonesia nomor 23 /POJK.03/2018 tentang Penerapan Manajemen Risiko bagi bank Pembiayaan Rakyat Syariah, dan Pedoman fungsi audit intern, sebagaimana diatur dalam Surat Edaran Otoritas Jasa Keuangan nomor 12 /SEOJK.03/2019 tentang Penerapan Fungsi Audit Intern bagi Bank Pembiayaan Rakyat Syariah, dan pedoman pengadaan Barang dan Jasa, sebagai acuan dapat digunakan Perpres 16 Tahun 2018 Tentang Pengadaan Barang/Jasa Pemerintah

3. Strategi Pengembangan dan peningkatan kinerja BPRS dan Kesejahteraan Umat.

1) Melengkapi Kebijakan dan Pedoman berkaitan dengan Tata kelola BPRS, menyangkut Kebijakan dan Pedoman Tata kelola, Fungsi kepatuhan, Penerapan manajemen risiko, dan fungsi audit intern, dan Kebijakan serta pedoman penunjang lainnya, sehingga akan mempermudah dan memberi kenyamanan dalam melaksanakan kegiatan usaha BPRS.

2) Menyempurnakan dan menyesuaikan Pedoman pedoman operasional baik dibidang Penghimpunan dana, penyaluran dana maupun jasa Syariah lainnya, sehingga mempermudah dan memperlancar kegiatan operasional syariah BPRS Daarut Tauhid.

3) Melakukan pemetaan Sumber Daya Insani dan struktur organisasi dalam rangka menetapkan jumlah sumber daya insani yang sesuai dengan beban kerjanya. Selanjutnya dapat dilakukan penambahan pegawai dalam rangka memenuhi kebutuhan perusahaan juga dapat menciptakan lapangan kerja.

4) Meningkatkan kualitas sumber daya Insani melalui Pendidikan dan pelatihan mandiri maupun kerjasama dengan 
lembaga keuangan syariah dan pihak pihak yang menyelenggarakan pendidikan.

5) Melakukan sosialisasi produk kepada pengusaha UMKM dan melaksanakan promosi agar keberadaan BPRS Daarut Tauhid lebih diminati.

6) Menciptakan inovasi produk produk syariah yang lebih menarik dan lebih bersaing dengan BPRS atau bank/lembaga keuangan lainnya.

7) Meningkatkan pemberian pembiayaan kepada para pengusaha UMKM dengan pelayanan prima, sehingga mempunyai dampak positif baik untuk BPRS Daarut Tauhid juga memberi dampak terhadap peningkatan kesejahteraan pengusaha UMKM juga meningkatkan kesejahteraan para pegawai UMKM.

8) Melakukan pendekatan dengan Lembaga pendidikan terutama lembaga pendidikan islam dan swasta yang ada di wilayah cimahi dan sekitarnya sehingga akan menambah sumber penghimpunan Dana.

Berdasarkan upaya Tim Pengabdian terhadap BPRS Daarut Tauhid memberikan sumbangan pemikiran dan konsep konsep, sehngga terdapat peningkatan kinerja baik dalam bidang penghimpunan dana maupun dalam bidang pembiayaan kepada UMKM, perbaikan tata kelola termasuk penyempurnaan Pedoman pedoman kerja dan pembuatan pedoman kerja yang belum ada, Penataan jaringan kantor, mengikutsertakan pendidikan dan pelatihan pegawai baik internal maupun eksternal dalam rangka meningkatkan kualitas sumber daya manusia.

Upaya peningkatan kinerja dan perbaikan tata kelola BPRS Daarut Tauhid dilakukan secara berkesinambungan dengan berlandaskan pedoman yang memadai yang dituangkan dalam Rencana Bisnis tahunan maupun Rencana Bisnis Jangka Panjang.

\section{KESIMPULAN}

1. Sasaran kegiatan pengabdian masyarakat ini tercapai dengan baik yang mana terungkap bahwa kegiatan usaha BPRS Daarut Tauhid telah sesuai dengan prinsip prinsip syariah sesuai peraturan perundang-undangan yang berlaku.

2. Berdasarkan materi yang telah disampaikan sesuai peraturan perundang-undangan yang berlaku dan selanjutnya keseluruhan materi telah dirangkum dalam aplikasi ceklis/self assesment sebagai alat control terhadap hal hal yang telah dilaksanakan, masih dalam proses dan belum dilaksanakan dapat dijadikan acuan untuk melengkapinya

3. Strategi Pengembangan dan peningkatan kinerja BPRS dan Kesejahteraan Umat akan dilakukan perubahan baik dari segi sumber daya manuasi, Teknologi dan memperluas jaringan sehingga bisnis BPRS berkembang dan terciptanya kesejahteraan umat.

4. Pengabdian masyarakat memberikan manfaat untuk peningkatan kinerja BPRS Daarut tauhid baik jangka pendek maupun jangka panjang.

\section{DAFTAR PUSTAKA}

Agoes, Sukrisno 2011. Etika Bisnis Dan Profesi Tantangan Membangun Manusia Seutuhnya, Jakarta: Salemba Empat

Johnson, G. dan Scholes, K. (2003). Understanding Strategy

Development", dalam Strategic Leadership and Educational Improvement. Buckingham: Open University Press.1

KNKG. 2006. Indonesia's Code of Good Corporate Governance. Jakarta: National Committee on Governance.

Peraturan Otoritas Jasa Keuangan Nomor 12/POJK.01/2017 Tentang Penerapan Program Anti Pencucian Uang dan 
Pencegahan Pendanaan Terorisme di Sektor Jasa Keuangan.

Peraturan Otoritas Jasa Keuangan Nomor 3 /Pojk.03/2016 Tentang Bank Pembiayaan Rakyat Syariah.

Peraturan Otoritas Jasa Keuangan Nomor 31/POJK.05/2014 tentang Penyelenggaraan Usaha Pembiayaan Syariah.

Peraturan Otoritas Jasa Keuangan Republik Indonesia nomor 23 /POJK.03/2018 tentang Penerapan Manajemen Risiko bagi bank Pembiayaan Rakyat Syariah.

Peraturan Otoritas Jasa keuangan Republik indonesia nomor 24 /POJK.03/2018 tentang Penerapan Tata Kelola bagi Bank Pembiayaan Rakyat Syariah.

Peraturan Presiden Nomor 16 Tahun 2018 Tentang Pengadaan Barang/Jasa Pemerintah.

Surat Edaran Otoritas Jasa Keuangan nomor 11 /SEOJK.03/2019 tentang Penerapan Fungsi kepatuhan bagi Bank Pembiayaan Rakyat Syariah

Surat Edaran Otoritas Jasa Keuangan nomor 12 /SEOJK.03/2019 tentang Penerapan Fungsi Audit Intern bagi Bank Pembiayaan Rakyat.

Undang-undang nomor 21 tahun 2008 tentang Perbankan Syariah. 